\title{
Supervised Internships and their Lessons: Challenges and Experiences with Teaching Degree in Computer Science in Brazilian Scenario
}

\author{
Pasqueline Scaico, Thaíse K. L. Costa \\ Department of Exact Sciences - Federal University of Paraiba \\ Rio Tinto, PB 58297-000, Brazil \\ \{pasqueline, thaise\}@dce.ufpb.br
}

\begin{abstract}
In Teaching Degree courses in Brazil, the internship intends to complement the student's graduation process, considering this field of work as an object of investigation and critical reflection on the environment which is around it. However, when it is related to Teaching Degree in Computer Science which forms educators to this area, some difficulties preclude the achievement of the internship in its fullness due to the absence of educational policies which may establish the performance of these teachers. Despite the incentive to actions, which involve the teaching of Computer Science in basic education in Brazil, Computer Science does not make part of any curriculum in schools. Trying to encourage this dialogue, this paper presents part of the scenario of Computer Science education and of the internship's activities in Teaching Degree courses, showing its organizational structure and its directions of activities that provide experiences with teaching. The research also represents the challenges and the lessons learned while conducting internship disciplines in a specific course.
\end{abstract}

Keywords: Supervised internship, Computer Science education, Teaching Degree in Computer Science.

\section{Introduction}

The internship intends to create a space of construction for meaningful learning. Its objective is to complete the student's graduation process, considering the field of work as an object of investigation and critical reflection from the links with the graduation course disciplines [1]. It is necessary to overcome the view of instrumental practice so that the internship is going to be seen as a true field of knowledge. Gonçalves and Pimenta [2] affirm that the internship consists in searching for the approximation of reality in which the trainee is going to work. Thus, we are looking for overcoming the view that the internship is only the practical part of the course. It is a field that the leads to reflection from reality.

Pimenta [3] states that the internship during the graduation course is a theoretical activity which enables the instrumentalization of the teaching activity of changing the reality. This view has been confirmed in Pimenta and Lima [1], when they affirm that it's a theoretical activity which integrates "knowledge, reasoning, dialogue and intervention". Within this context, many universities conduct this part of college students' formation as just a formality. This dichotomy about theory and practice creates a conflict of ideas about the perception of what the internship is and it makes the several planning which conducts the student's formation stay away from the internship proposal as a field of knowledge production. A particular situation of conflict about the internship objectives happens in many Teaching Degree in Computer Science courses, and it is emphasized by the joint of different conceptions of the internship and by the difficulty of constructing the professional's identity. Even that the Teaching Degree in Computer Science has been a reality for 15 years, this last problem is due to the fact that the education in Computer Science (CS) is still not studied in Brazilian curriculum.

According to governmental syllabi guidelines for Computer Science courses, the teaching degree should form, among other skills, a teacher who will be able to teach Computer Science in basic and technical education [4] [5]. Although these courses has been created and there are a hundred of them all over Brazil, the educational policies have not advanced to keep this professional inside school spaces. Bezerra and Silveira [6] affirm that sometimes the professionals with a teaching degree in Computer Science cannot find a position in work market which is consistent with their profiles, and so, they start to compete with professionals of other work areas for job vacancies.

This problem also happens during the internships because the schools do not know the graduate's role, even though hes an important agent for the education in the future, which should provide citizens with certain fluency in technologies usage and also necessary abilities to solve problems that may be reinforced with Computer Science study. This fact brings a certain difficulty to the full range of the internship proposal, in which the graduate could exercise the teaching activity of changing reality defended by Pimenta [3]. 
In general, exploring CS at schools may have three forms. Firstly, the computer is shown as a general purpose tool and it works as a mechanism to facilitate the completion of repetitive tasks. Another situation is that one where the basic education teacher has learned how to use the technology as a facilitating resource for teaching and learning. The third, Computer Science is used as a purpose. In this last axis, there is a great discussion on the possibility of developing new abilities which are explored, for instance, through the teaching of programming and computational thinking. For many Teaching Degree courses, the pedagogical conception of the curriculum tends to emphasize the development of abilities which are more related to the creation of educational software that will be a mechanism for technological mediation. Nevertheless, the formation of individuals, able to teach Computer Science and aware of their transformative roles within the school, is something that should not be lost due to the difficulties put in the acting field of these teachers. Thus, the internships are highly relevant to establish the challenges and opportunities which are presented to them.

Since the internships possibly represent the systematization of first teaching experiences, the analysis of internship regulations for Teaching Degree in Computer Science courses is an interesting object of investigation so that it will be possible to identify how the teaching degrees are coping with the insertion of egress students in Brazilian schools context. The current paper presents a characterization of the disciplines of mandatory supervised internships at some universities where such courses are being offered all over Brazil. It is also presented a historical of how the Federal University of Paraiba has been adapting such disciplines within its Teaching Degree in Computer Science course, depending on the trainees' perception, on schools' scenario and on the maturation of Computer Science teaching in basic education in a local context. Thus, we look for discussing the attempt to create more productive and enriching spaces for their academic's formation as well as to dialogue about the teaching identity which the graduate in Computer Science is (or should be) taking in schools. This way, this paper proposes to enrich the discussions about the mandatory internships in Teaching Degree in Computer Science.

The article is organized as follows. Section 2 presents an overview about the education on CS. Section 3 shows a reading about how some Teaching Degree in Computer Science courses in Brazil regulate their disciplines of mandatory internships, an important step to understand the view of these courses in relation to the role of the internships in the formation of a teacher who will use Computer Science teaching as a way or purpose. Section 4 shows how the Federal University of Paraiba regulated its Teaching Degree in Computer Science and its first experiences in conducting the internships activities. Section 5 presents the lessons learned over six years (20062012). Section 6 shows the final considerations of this article.

\section{The Scenario of Education in Computer Science}

The process of inserting new technologies in Brazilian schools has gained ground due to governmental policies of supporting the technological innovation, such as the National Program of Educational Technology, created in 1997, and Broad Band in Schools, which have the objective of improving the teaching and learning processes [7]. However, such resources are not still enough for the wide computerization of public education, as alerted by Priecth and Pazeto [8].

Besides encouraging the teaching and learning process with new technologies, it is necessary to develop other abilities for the fluency in its effective usage. Therefore, more than train teachers for the use of technologies in teaching practice, it is necessary to train students so that they may benefit from the possibility of learning how to think of a more analytical and systemic way, helping and stimulating, mainly, the resolution of problems. To that extent, the introduction to computational and algorithmic thinking in basic education is encouraged. In an interview in [9], Roberto Bigonha affirms that "the same way we should know how to read, write and calculate, we need to be able to apply technics based on abstraction usage, to evaluate commitments of several kinds, to plan the execution of tasks step by step, to recognize strengths and weaknesses"1.

Many countries have been discussing the implementation of a minimum curriculum for Computer Science teaching in basic education. Jones and colleagues [10] presented an interesting report in which they show what some countries such as England, Scotland, Germany, India, Israel, New Zealand, South Korea and the USA, have been doing to introduce education in Computer Science in schools. Particularly, in the USA, the model shows the range of the so-called Imperative Education, in which the importance of learning how to develop the computational thinking is highlighted [11]. As Bell [12] points out, many organizations such as CSTA (Computer Science Teachers Association) - supported by ACM (Association for Computing Machinery) and Google; ISTE (International Society for Technology in Education) and NAEP (National Association for Educational Progress) contribute with syllabus models, patterns and guides to establish Computer Science teaching in schools. Therefore, it is understood that the introduction of Computer Science in schools is intellectually important because it establishes the possibility of multiple future professional paths and the development of useful capacities of problem solving.

In Brazil, the Teaching Degrees in Computer Science are responsible for graduating professionals who have, among other competences, a profile for teaching Computer Science in basic and technical levels. According to the Brazilian Society of Computer Science, the Teaching Degree in Computer Science is a course focused on teacher training that has as a main factor the specialized and multidisciplinary formation, in which the licensed professional must dedicate his efforts to the basic education in Computer Science teaching, giving some emphasis to the last

${ }^{1}$ (our translation) 
grades in primary school and high school, including the technical education as well. Since 1999, through a Committee of Computer Science Teaching Experts, Brazilian Society of Computer Science has been showing the benefits of absorbing individuals graduated in CS [4]. Despite the schools syllabus do not include any content focused on education in Computer Science yet, since 2004 the Degree in Computer Science Work Group (GT-3), also from Brazilian Society, has approved a proposal to include contents about Computer Science in high school.

After verifying that the Ministry of Education and Culture (MEC) has been authorizing the opening of Teaching Degree in Computer Science courses, on-site/classroom courses and distance learning courses as well, all over Brazil, it may be evident how important the creation of human resources for Computer Science teaching is. Through e-MEC System (http://emec.mec.gov.br) it is possible to access a list of the courses which are in activity. Although this system cannot disclose the real situation of these courses, it is still used by MEC as a central source of information.

After searching for words such as "Computer Science and "Informatics" in the system, we verified the existence of 67 universities that offer a total of 105 Teaching Degree courses in the field of Computer Science, with 93 on-site courses and 12 distance learning courses, the first of which created by the University of Brasilia (UnB). Yet one and a half decade later, small advancements were made in relation to the ingress of the professional in school spaces and sometimes the egress student ends up looking for other professional possibilities in the field of technology, as affirmed by Priecth and Pazeto [13]. This fact may also be influenced because some courses assume the technology mediation of other areas as the principal teaching activity of their students.

Therefore, the difficulties might limit the experience of the internships in Teaching Degree in Computer Science in Brazil because the teachers face an area of education that is not consolidated and whose professional is barely recognized in school environment. All these obstacles further increase the challenges that the professors of these courses have, because they need to ensure the construction of students' teaching identity, so that they become future educators in Computer Science who may be able to fight for their place in the job market as well as taking on the challenge of defending educational policies for the inclusion of education in Computer Science in school curricula.

\section{Internships in Teaching Degree in Computer Science: a Cutout}

According to the Commitee of Experts in Computer Science Teaching in Brazil (in Portuguese, CEEInf Comissão de Especialistas de Ensino de Computação e Informática no Brasil) [4], Teaching Degree in Computer Science courses aim to prepare teachers who will be able to form autonomous citizens regarding the technology usage and who will be able to collaborate with the economic and social development of Brazil. It is highlighted therefore the importance of the introduction of computational and algorithmic thinking in basic education as a resource to develop the problem solving ability. This educator must be able to teach basic concepts of Computer Science as well as must able to teach with a reflexive and critical point of view, proposing and coordinating teaching and learning computer aided projects which foster the interest in investigation and research.

In the Pedagogical Plans of the courses there must be all strategies and the curriculum necessary to achieve the egress' profile. So, the internships regulation is an important component to establish the ways and the fields where the first experiences with the pedagogical practice will happen. In order to understand the organization of the internships in those courses, a research about the mandatory internships regulation in courses offered all over Brazil was done in 2012.

Firstly, the access to information was performed by searching some Teaching Degree courses websites. However, it has been found that the documents and regulations for internships were not available for their visitors. Therefore, it was necessary to make direct contact by e-mail or telephone calls with many Teaching Degree courses spread all over Brazil. Finally, from the 28 courses contacted, only 15 have provided the necessary information and the regulation about the mandatory supervised internships. The courses that have been analyzed belong to the following institutions: Federal University of Bahia, Federal University of Paraiba, State University of Paraiba, Technological Institute of Rio Grande do Norte, Federal Rural University of Pernambuco, University of the State of Bahia, Natalense College for the Development of Rio Grande do Norte, University of Caxias do Sul, University of Santa Cruz do Sul, Farroupilha Federal Institute of Education, Science and Technology, Cenecista College of Osorio, State University of the North of Parana, Colleges of Dracena, Feevale University and University of the State of Mato Grosso.

Regarding the distribution of the minimum course load dedicated to internship disciplines, we observed that most of the courses have their course load organized in four disciplines, as it can be seen from Table 1. However, it is noticed that there are courses in which the distribution is not organized according to the regulation.

Table 1: Course load distribution in Supervised Internship (SI) disciplines

\begin{tabular}{ccccc}
\hline QUANTITY & SI-I & SI-II & SI-III & SI-IV \\
OF COURSES & & & & \\
\hline
\end{tabular}




\begin{tabular}{ccccc}
$\mathbf{1}$ & 60 & 120 & 120 & 120 \\
$\mathbf{1}$ & 45 & 120 & 120 & 120 \\
$\mathbf{1}$ & 60 & 60 & 120 & 120 \\
$\mathbf{3}$ & - & 100 & 150 & 150 \\
$\mathbf{5}$ & 100 & 100 & 100 & 100 \\
$\mathbf{4}$ & \multicolumn{4}{c}{ No recommendation } \\
\hline
\end{tabular}

Analyzing how the internships are organized it has been noticed the predominance of three macro-actions: $\mathrm{i}$; observation, ii. diagnostic action and iii. conduction of classes. Only half of the courses have in their regulations some determination about the kind of activity that must be performed in each internship. Although it has not been found in all the courses which were investigated, this characteristic is important because it gives an assurance that the practice of the internships is an evolutionary process, where the students can try increasing levels of maturation of teaching practice in their acting field as well as of school management itself.

Approximately in $90 \%$ of the courses, the internships activities are directed to primary, high and technical school levels. However, teaching in an infantile level within the regulation of one of the courses was cited as well as teaching in a technological level within the regulation of another one. It is worth mentioning that the acting field of a professional, who has a Teaching Degree in Computer Science, in schools includes the final grades of primary school, high school and technical school as well.

Regarding the activities proposed to the trainees, we have observed a great prevalence of teaching to train teachers how to use basic Computer Science and learning objects. The researches of Silva and Gentil [14] and Rodrigues and Milhomem [15], which discuss the different aspects of the mandatory internships in their Teaching Degree in Computer Science courses, always show that most part of the trainees' experiences is within the Computer Science in education. It suggests that there is certain fragility in the students' formation regarding their identity construction as educators in Computer Science not only as Computer Science teachers. It is important to mention how necessary is to make the students develop projects and activities which may become the a facilitator of the learning process, however, the undergraduate students' formation must be complete and it must reach all the competences described in the graduates' profile from such courses.

This way, it is necessary to stimulate the experience to activities which allow Computer Science teaching as a science. Most curricula of the Teaching Degree in Brazil invest in a solid formation in Computer Science and math so that the professional, having a contact with the school context, may bring contributions to an education system that comprehends, among other things, the importance of making young people understand more about Computer Science to use such knowledge in their daily lives.

The next sections of this article will present the experience that the Teaching Degree in Computer Science from the Federal University of Paraiba has been acquired while conducting its internships and the actions which have been implemented so that the trainees have the opportunity to take on practices that encourage Computer Science teaching.

\section{The Teaching Degree in Computer Science at the Federal University of Paraiba and its Internships}

Complying with the governmental curriculum guidance, during the second half of 2006, the Federal University of Paraiba created the Teaching Degree in Computer Science course in the city of Rio Tinto, in the countryside of Paraiba where the population has 20.000 inhabitants in urban zone.

According to the regulations of its internships, the activities should create the students' perception about their teaching identities and about their acting fields, permitting the exploration of opportunities that give them: the conditions for the professional experience; the development and implementation of projects to insert the computer in teaching and learning process; observation and acquisition of knowledge along with the teaching professionals; and the contact with the educational reality in the region.

The internship regulation was established to provide the trainee with such opportunities and to contribute with the formation of a professional who is going to be able to teach Computer Science in primary school, in high school and vocational education as an essential subject to formation of the new millennium student; with the formation of an educator who may contribute and is able to create innovations in teaching and learning process; and with the formation of a professional with critical thinking, able to specify educational software and distance learning systems and able to answer technological matters as well as pedagogical ones. The internships course load has 405 hours and it is organized in four disciplines with different characteristics, as it can be seen from Table 2.

Table 2: Characteristics of the internship disciplines

\begin{tabular}{llll}
\hline $\begin{array}{l}\text { Internshi } \\
\mathbf{p}\end{array}$ & $\begin{array}{l}\text { Academic } \\
\text { semester }\end{array}$ & Course load & Characteristics \\
\hline I & $6^{\text {th }}$ & $45 \mathrm{~h}$ & Observation with a reflection on pedagogical activities developed in
\end{tabular}




$\begin{array}{lll}\text { II } \quad \text { 120h } & \begin{array}{l}\text { primary schools. The student will submit a detailed report about the } \\ \text { internship involving a description of the phenomena observed in the } \\ \text { classroom. Due to the reality observed, this report must present feasible } \\ \text { solutions or proposals. }\end{array} \\ \text { III/IV } & \begin{array}{l}\text { Observation with a reflection on pedagogical activities developed in } \\ \text { high schools. The student will submit a detailed report about the } \\ \text { internship involving a description of the phenomena observed in the } \\ \text { classroom, bringing a critical reflection about them. Due to the reality } \\ \text { observed, this report must present feasible solutions or proposals. }\end{array} \\ 8^{\text {th }} \text { e } 9^{\text {th }} \quad 120 \mathrm{~h}(\text { each) } & \begin{array}{l}\text { Development of activities which have characteristics of observation- } \\ \text { diagnostic action in primary schools, high schools and technical } \\ \text { schools, or any other institute, company, institution or public agent } \\ \text { which may develop teaching activities }\end{array}\end{array}$

The first class of a internship discipline occurred in 2009. The course could provide four internship groups working in parallel only during the second half of 2010. The Subsection 4.1 shows part of what was initially experienced during the conduction of the internships of the courses here described.

\subsection{The First Experiences of the Course with the Mandatory Internships}

Since the beginning, each internship plan tried to follow the guidelines of the regulation defined within the course which was altered aiming for the updating of the rules of use and the clarifying of the course load of practical activities throughout the internships. Finding internship fields and activities which may help the students' formation was one of the problems faced by the coordination. During the three academic semesters, the coordination has made partner with municipal and state schools from the region, which had Computer Science labs but neither had any skilled professionals to work in such places nor additional activities which might include the teaching of Computer Science.

The first activities of the mandatory supervised internship happened in municipal schools from the region. These activities have made the trainees observe and reflect on the pedagogical activities done by teachers of other areas of expertise as well as on the conjecture surrounding the application of Computer Science at schools. For purpose to illustrate, we list some actions developed:

- Visits to public primary schools for observation so that it could be possible to check the suitability of the school during the insertion of Education in Computer Science projects as well as the use of technologies as pedagogical tools;

- Collecting and analyzing data on the profile of students, teachers and other employees in relation to the access and to the knowledge in Computer Science

- Monitoring of classes for observation and research of educational tools which could help the learning process.

An interesting fact detected by the first experiences of the trainees was the encouragement to the deployment of extension projects that could implement some students' aspirations on the school reality. Among them, there is the introduction to computer which later on could be taught as a facilitator in the learning process. One of the inspired projects from these internships was teaching technology skills, which involved about eight Teaching Degree students in planning and conducting workshops in public schools for an average number of twenty-nine teachers of municipal schools, with the goal of outlining new proposals for teaching and learning using the computers [16].

Two important aspects have been perceived with the lessons learned over the years while conducting internships disciplines. Firstly, the model of monitoring of internship classes by the supervisor teacher did not seem to contribute to the existence of a systemic view of the evolution of the groups since their first discipline to their last one. This type of monitoring sometimes caused the breakdown of activities when another teacher started to teach the discipline and did not always lead the trainees in what it could be the evolution of the activities that were being developed. Secondly, we realized that the internship fields which were explored did not favor teaching practices for education in Computer Science, not quite meeting the profile of the graduate. This fact brought a great concern for the professors and students who saw a huge dichotomy created between the profile of graduates and the attitude towards the reality which the students were being subjected. A survey was conducted with a sample of the student body so that the facts could be ascertained, as it can be seen from Subsection 4.2

\subsection{The Students' Perception about the Mandatory Internships}


It has begun a process of collecting information with the objective of identifying weakness and potentialities of the internship disciplines of the course after a few students have graduated and others have enrolled in such disciplines. An online questionnaire was provided and it sent by e-mail in the late half of 2012 so that students could write about their internship experiences. Twenty one students responded to the survey, from a total of about 96 students who had enrolled in the internship disciplines or had already graduated. Among the participants, about 50\% already completed the total course load required for internships and 35\% were enrolled in the final disciplines of the course.

When the students were asked about their experience with the practice in external spaces, i.e. their participation in activities, including teaching in school or non-school settings, 38\% of them affirmed they had not had the opportunity to experience any situation of this nature in an environment outside of the university. This percentage of almost $40 \%$ was mostly made up of students who were attending Mandatory Internship II and Mandatory Internship IV disciplines. This fact was explained because one of the internship fields allowed are the project laboratories which are being developed in the course and aim at the production of educational software, besides other products.

Another relevant data was that $57 \%$ of the trainees had different teachers supervising their activities across the four internship disciplines. When the students were asked about the advantages and disadvantages of this supervising approach, about $90 \%$ of responses indicated more benefits in the guidance model in which a teacher accompanies a group of trainees from the first discipline to the last one, and different advantages of this model were cited such as: i. facilitation for the teacher to follow the student's trajectory, which it can improve the planning of their future activities, ii. plan constructions which set annual actions that can be continued by the students throughout several internship disciplines, thus ensuring the continuity of activities and iii. greater possibility for the teacher to conduct actions that consist in broader practices for the formation of the graduate's profile.

Regarding the weaknesses of the internship disciplines, the students complained about the following problems: $\mathbf{i}$. the establishment of internship fields for Computer Science teaching, ii. the flexibility of the actions of the internships that often contemplate the teaching of basic Computer Science or teacher training, due to the isolated internship fields obtained and iii. poor performance of trainees with regard to conducting discussions with schools and school managers from the region about the importance of teaching Computer Science in basic education.

\section{Lessons Learned}

The training of human resources for Computer Science teaching in basic education in Brazil is challenging. Undergraduate courses responsible for such training, such as the Teaching Degrees in Computer Science, face several problems when conducting the mandatory supervised internships. Thus, many of these courses often take an easy way out when they need to find internship fields: to invest in the practice of trainees with the Educational Computer Science. However, this option is not always the best decision for the formation of a qualified Computer Science teacher who must always take the challenges posed as well as position himself before the scenario in order to be able to change the panorama of the Computer Science teaching in Brazil. The report here described shows the commitment of a course in enabling the best possible experiences for undergraduate internships through Computer Science teaching in schools.

The approach used in the allocation of professors to supervise the internship disciplines has been treated differently after the perception of the internships in the students' point of view. Trying to enhance the supervision, caring for the formation of the trainees, we opted for a new model of supervision (guidance), called supervising model per class in which a professor started to follow the same group of students along the four internship disciplines.

The facts also evidenced the great fragility of the course in relation to the establishment of internship fields that could offer varied possibilities of the trainees' performance in education in Computer Science, as recommended by the governmental curriculum guidelines. Considering the lack of qualified teachers in basic computer use at schools, many activities were eventually designed to meet this demand, which is extremely important but it limited the formation of the undergraduate students either in relation to their teaching practice or to their identities as Computer Science teachers. Due to this scenario, plenty of internships occurred internally, in the environment of projects which were being developed within the course, a fact that has impoverished the view the students should build on their profession and challenges posed.

Attempting to improve this issue, firstly, new internship fields were sought in the private sector, in schools which already had computer and educational robotics classes as a non-mandatory component. Thus, the trainees could observe and reflect on the computer classes planning, know the materials used and the methodologies to teach technology in an interdisciplinary way in different school levels as well as to follow the lessons taught by the school teachers.

Due to the trainees' reflection and one of the schools director's interests in working actions which could introduce Computer Science to elementary students, a project has been elaborated so that the benefits of the computational thinking usage and some methods for its practical work could be cleared. Such project was based on the activities from the Computer Science Unplugged ${ }^{1}$ book and its development involved students from different internship disciplines. The activities have been organized through a competition made of four activities from the book and they have been adapted so that they could be done with a group of sixty-nine $9^{\text {th }}$ grade students. 
The initiative to start working the computational thinking through this project in this school was extremely important to help the trainees trust themselves and to increase their self-esteem as well. They started then to realize different opportunities as well as their teaching identity. Besides, the Computer Science teacher's challenges in basic education have been discussed in a much more entrepreneur and proactive perspective.

Another group of students have been motivated by this first project and then they sent to the Education Board from another city a project which explored the pedagogical robotics and the computational thinking as additional activities in full time schools. This experience gave the opportunity to 600 students to learn some programming through robotics and computational thinking in an interdisciplinary context [17].

Regarding the presence of the Teaching Degree in Computer Science trainees in schools, we observed that these professionals' role has been not understood by the directors, teachers and students yet. Therefore, as a learned lesson too, it is important the graduate try to emphasize the pedagogical potential of the computational thinking for other disciplines and for Computer Science, always showing what is behind his activities.

We may say that these results were a product of the supervising model that was adopted by the trainees group, which has made the supervising teacher and the trainee get much closer, and finally helping the trainee to perform in a way his teaching activity was able to transform the society.

\section{Final Considerations}

The experience obtained with the internship in the on-site Teaching Degree in Computer Science course from the Federal University of Paraiba has given the possibility to reflect on such practice as a field of knowledge and as an extremely important space for the formation of the teacher in Computer Science. The difficulties found in the acting field of Teaching Degree student as well as the interest in improving the internships activities help change the guiding model which has better organized the activities.

According to the survey conducted with the students, the supervising model in which the supervisor accompanies a group over the internship periods allows the advisor perceives the developments and closely participates in the process of formation of the student, considering the acting field as an object of inquiry which directs the actions and proposals to reality transformation. Nevertheless, this experience report is not intended to set a standard, but to show that even with the difficulties presented, improvements can be achieved in this so important activity for the formation of a professional, the mandatory internship.

It was observed from experience that: i. teaching degree courses have the mission to start before society through school spaces a discussion on the importance of using the CS as a way and as a purpose in order to make better qualified schools, able to form young people with the skills to solve problems, to deal with the complexity and to know how to use the abstraction; ii. Capturing the acting field must be intensified so that it can be possible to diversify the actions of undergraduates in Computer Science (instrumentalization of Computer Science as a teaching mechanism, Computer Science teaching, developing educational solutions, among others), without losing sight of the importance of educating students about their responsibility for building projects, built from the supervision of their professors, facilitating the discussions in Municipal Boards of Education and at private institutions; iii. despite the problems in public schools, there has been young people's great interest in understanding more about topics related to $\mathrm{CS}$, such as computer programming and computational thinking, which means that many projects can be started from the engagement of the students themselves and it is necessary for them to become not only good information consumers but producers of generated knowledge from the fluency in technology. These issues are challenging but they can be treated inherently in the acting field of the trainees and they will be very useful to complement the student's training in the field of humanities. From the point of view of the operation of the internship activities, the supervising model, in which the professor follows the same group of students, was better accepted by students and it has shown effectiveness.

Finally, it is worth remembering that it is possible that the Teaching Degree in Computer Science students are partakers within the process of Brazilian education improvement by simply being oriented to form their political posture in the existing scenario and establish a professional identity as well. Therefore, their teaching and learning process becomes full and the education in Computer Science becomes a possible target, initially as complementary activities but which arguably contribute to a better school.

\section{References}

[1] S. G. Pimenta and M. S. L. Lima, Estágio e Docência, 6th ed., Ed. São Paulo: Cortez, 2011.

[2] C. L. Gonçalves and S. G. Pimenta, Revendo o ensino de $2^{\circ}$ grau, propondo a formação do professor, Ed. São Paulo: Cortez, 1990.

[3] S. G. Pimenta, O estágio na formação de professores: unidade, teoria e prática?, São Paulo: Cortez, 1994.

[4] Comissão de Especialistas de Ensino de Computação e Informática - CEEInf, Diretrizes Curriculares de Cursos da área de Computação e Informática, Ministério da Educação, 1999. Available: http://www.mec.gov.br/. 
[5] E. Matos and G. da Silva, "Currículo de licenciatura em computação: uma reflexão sobre perfil de formação à

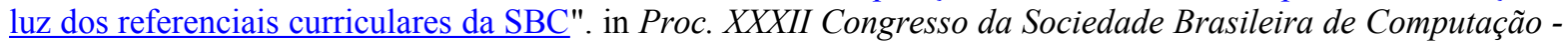
XX Workshop de Educação em Computação, Curitiba, PR, Brasil, 2012.

[6] L. N. M. Bezerra and I. F. Silveira. "Licenciatura em Computação no Estado de São Paulo: uma Análise Contextualizada e um Estudo de Caso". in Proc. XXXI Congresso da Sociedade Brasileira de Computação - IX Workshop de Educação em Computação, Natal, RN, Brasil, 2011.

[7] Ministério da Educação, Educação: Para a educação melhorar, todos devem participar, Available: http://portal.mec.gov.br.

[8] S. S. Priecht and T. A. Pazeto, "Análise, Sugestões e Perspectivas de um Curso de Licenciatura em Informática" in Proc. XXIX Congresso da Sociedade Brasileira de Computação - XVII Workshop sobre Educação em Computação, Bento Gonçalves, RS, Brasil 2009.

[9] A. S. S. (pub.) (2011, Ap/May/Jun). A Computação como CIência Básica. Revista da Sociedade Brasileira de Computação. 15th Ed. pp. 8 -11.

[10] S. P. J. et al., "Computing at School International comparisons", Nov, 2011. Available: http://www.computingatschool.org.uk/data/uploads/internationalcomparisons-v5.pdf

[11] Computer Science Teacher Association CSTA. The New Educational Imperative: Improving High School Computer Science Education. Final Report of the CSTA. Curriculum Improvement Task Force. ACM Association for Computing Machinery. 2005.

[12] T. Bell, P. Andreae and A. Robins, "Computer Science in NZ high schools", in Proc. 12th Australasian Computing Education Conference (ACE 2010), Brisbane, Australia, 2010.

[13] S. S. Priecht and T. A. Pazeto, "Mapeamento de Cursos de Licenciatura em Computação seguido de Proposta de Padronização de Matriz Curricular", in Proc. XXX Congresso da Sociedade Brasileira de Computação XVIII Workshop sobre Educação em Computação, Belo Horizonte, MG, Brasil, 2010.

[14] C. C. Silva and H. S. Gentil, "A Formação do Licenciado em Computação: Um estudo Sobre as Concepções Acadêmicas em Relação ao Estágio Supervisionado", Revista Cultura, Educação e Sociedade, vol. 1, n.2, pp.305-314, Jul./Dec., 2011.

[15] W. F. B. Rodrigues and A. L. B. Milhomem, "Estágio Supervisionado do Curso de Licenciatura em Computação: Perspectivas em Relação à Informática Educativa", in Proc. II Congresso Internacional de Educação, Ponta Grossa, PR, Brasil, 2010.

[16] T. Costa, C. Silva, A. Rebouças, L. Alencar, E. Lopes, V. Dantas, F. Souza, E. Assis, J. Dantas, L. Almeida, M. and V. Andrade. "Formação Tecnológica de Professores do Município de Rio Tinto: Um Relato de Experiência", in Proc XXII Simpósio Brasileiro de Informátuca na Educação - XVI Workshop de Informática na Educação. ISSN:2176-4301, Aracaju, SE, 2011.

[17] M. S. Henrique, F. O. M. Cunha, E. R. Macedo, P. D. Scaico, "Um relato histórico da prática docente em disciplinas de estágio contado por estudantes da Licenciatura em Computação", in Proc. Congresso da Sociedade Brasileira de Computação - XXI Workshop sobre Educação em Computação, Maceió, AL, 2013. 